\title{
EXUMANDO CORPOS DE ÍNDIOS: A EMERGÊNCIA ANACÉ E OS NOVOS DRAMAS ÉTNICOS E DESENVOLVIMENTISTAS NO NORDESTE BRASILEIRO
}

\author{
POTYGUARA ALENCAR DOS SANTOS ${ }^{1}$
}

$U n B$

\begin{abstract}
RESUMO: Embora com raros registros entre os estudos em etnologia política dos grupos indígenas do Nordeste brasileiro, o despertar do etnônimo anacé, na costa oeste do Ceará, vem sendo notadamente importante à reflexão sobre os novos enclaves entre programas desenvolvimentistas e as atuais mobilizações de regimes de memória e de agência política em torno da certificação de direitos territoriais às populações indígenas da região. Ao artigo interessa analisar a reelaboração da etnicidade anacé a partir de dois eventos que fazem confundir uma narrativa da emergência indígena com os desdobramentos do drama desenvolvimentista nacional que construiu o Nordeste brasileiro como uma "regiãoproblema". Como se combina a presença indígena no cenário de implementação dos projetos de grande escala com essa caracterização tópica de uma região em processo de desenvolvimento das suas forças produtivas? E como essa composição rebate nas atuais mobilizações políticas anacé? Em vista de analisar essas questões, o texto propõe reflexões compartilhadas entre autores da etnologia política e da antropologia do desenvolvimento e da globalização.
\end{abstract}

PALAVRAS-CHAVE: Reelaboração étnica anacé; Projetos de grande escala; Etnologia política; Antropologia do desenvolvimento; Nordeste do Brasil.

ABSTRACT: Although with few records among studies in political ethnology of indigenous groups in Northeast Brazil, the awakening of the ethnonym anacé, on the west coast of Ceará State, has been especially important to considerations on the new frontiers of development programs and the current mobilization of regimens of memory and political agency around the certification of territorial rights for indigenous peoples in the region. The article analyzes the re-elaboration of the anacé ethnicity from two events that mix a narrative of the indigenous emergence with the national drama that stated Northeast Brazil as a problematic region in what regards development. How is the indigenous presence in a scenario of large-scale projects implementation combined with a region characterized as economically problematic? And how this compound affects the current anacé political mobilization? In order to analyze these issues, this paper proposes reflections shared by authors in political ethnology, development anthropology and anthropology of globalization.

\footnotetext{
${ }^{1}$ Doutorando pelo Programa de Pós-Graduação em Antropologia Social da Universidade de Brasília e mestre em Antropologia Social (PPGAS/UnB). É secretário do Laboratório de Estudos da Globalização e do Desenvolvimento (LEG - DAN/UnB) e membro pesquisador do Núcleo Multidisciplinar de Avaliação de Políticas Públicas (NUMAPP - UFC) e do Grupo de Estudos sobre Trabalho e Transformações Capitalistas (GET - UFC). E-mail: potyguara.alencar@gmail.com .
}

Espaço Ameríndio, Porto Alegre, v. 7, n. 1, p. 214-252, jan./jun. 2013. 
POTYGUARA ALENCAR DOS SANTOS - Exumando corpos de índios...

KEYWORD: Anacé ethnic re-elaboration; Large-scale projects; Political ethnology; Development anthropology; Northeastern Brazil.

[...] As escavações empreendidas na terraplanagem da área onde foi instalada a termoelétrica MPX Mineração e Energia Ltda., do grupo EPX, do empresário Eike Batista, trouxeram à superfície artefatos líticos e de cerâmica que não eram identificados com nenhum utensílio das populações viventes contemporaneamente na região. De certa forma, o movimento físico de escavação e a "escavação histórica" propiciada pelo fortalecimento do etnônimo Anacé compuseram um conjunto de eventos que resultaram nas várias movimentações territoriais e de grupos em torno da conflitiva entre representantes locais e representantes dos consórcios estatais-privados atuantes nesta região (Aldeia Anacé de Bolso. São Gonçalo do Amarante, Ceará, 20 de março de 2012. Diário de Campo M-2012, p. 182).

O que as mais recentes emergências indígenas do Nordeste brasileiro comunicam das atuais redes de desenvolvimento e do adensamento dos nexos produtivos do Estado, dentro da sua histórica corrida por nivelar assimetrias regionais internas? Se retomarmos a observação que Pacheco de Oliveira (1998) fazia, ainda na década de 1990, sobre o caso dos "índios misturados do Nordeste", quando lembrava que uma etnologia particular à região deveria enfocar não a luta conservacionista/preservacionista da Amazônia, mas sim a disputa latifundiária por garantia de terras produtivas às populações campesinas, podemos relacionar essa análise com o momento dos grandes projetos salvíficos daquela que foi tratada como a "regiãoproblema do Brasil" (FURTADO, 1981, p. 35). Nesse contexto regional, verificaremos que o despertar de etnicidades as mais variadas se realiza nas fronteiras entre os velhos regimes latifundiários superconcentradores de paisagens biofísicas férteis - serras úmidas, zona da mata e algumas planícies litorâneas - e as novas interferências dos projetos de grande escala que ocorrem do litoral ao sertão 
POTYGUARA ALENCAR DOS SANTOS - Exumando corpos de índios...

nordestino, invariavelmente. Projetos que vêm de uma longa família e ciclos de iniciativas desenvolvimentistas, mas que atualmente podem ser exemplificados por pelo menos dois deles: as iniciativas do Plano de Aceleração do Crescimento (PAC I e II) e, especificamente, a implementação macrorregional do projeto Eixão das Águas, com a transposição do rio São Francisco.

O caso da emergência indígena anacé, processo político de reetnização que se inicia em 1998, no interior das vilas campesinas de Bolso e Chaves, do município cearense de São Gonçalo do Amarante, Região Metropolitana de Fortaleza, é exemplar para se analisar tanto a sociologia comum do despertar de uma "identidade categórica" (BARRETTO FILHO, 1994) silenciada e invisibilizada historicamente por aparelhos civilizacionais, como também propicia uma reflexão sobre as redes de desenvolvimento que tentam superar as negatividades econômicas e políticas atreladas ao Nordeste do Brasil.

Por serem processos simétricos e correspondentes, embora com atores e interesses adversos - já lembrava uma noção de contato interétnico (CARDOSO DE OLIVEIRA, 1964) -, o desenvolvimento e as emergências indígenas se conformam em contextos muito particulares, onde as movimentações de grupos parecem interagir como programas e contraprogramas, decisões e contradecisões de atores que tentam tornar suas demandas hegemônicas frente às demandas de outros segmentos. No caso da emergência anacé, no litoral cearense, o "drama desenvolvimentista" (RIBEIRO, 2008), com as suas mais variadas expressões de impactos, desdobrou-se na intimidade da história particular do reaparecimento da denominação indígena e da sua organização política particular.

$\mathrm{Na}$ apresentação do caso da reafirmação da identidade anacé, intento tratar de dois registros etnográficos que flagraram as interações entre os operadores estatais e privados dos projetos portuários e industriais que atuam na chamada Costa do Pecém, no litoral oeste do Ceará, e as lideranças indígenas das aldeias de Bolso e Matões. Um desses eventos é um dia de reunião no Comitê Territorial dos Matões, quando estavam reunidos representantes das comunidades rurais e indígenas da região, dos consórcios empresariais e do governo estadual em torno do objetivo de "planejar" a ocupação territorial da região. O 
POTYGUARA ALENCAR DOS SANTOS - Exumando corpos de índios...

outro evento do qual trago o registro etnográfico é a minha visita à sede estadual da Fundação Nacional do Índio (FUNAI - Ceará), quando pude entrar em contato com um cacique anacé e com o superintendente da instituição.

Composições e reuniões concentradas do drama étnico e desenvolvimentista no Nordeste do Brasil: uma visada teóricometodológica

Esses instantes registrados pela pesquisa etnográfica serão analisados aqui a partir do conceito de "reuniões concentradas" (GOFFMAN apud GEERTZ, 1989)2. O conceito ressalta os atos instantâneos, os jogos corporais e de linguagem, o compartilhamento de ambientes institucionais por coletividades e seus códigos de intercomunicação. Esses encontros podem ser conflitivos, colaborativos e decisivos para o destino dos seus participantes dentro de certo espaço interacional. As reuniões concentradas são eventos que sempre gozam de certo grau de imprevisibilidade quanto ao que pode acontecer no interior do seu fluxo de interações, a despeito dos sistemas posicionais hierárquicos que fundamentam as relações entre os seus atores. Pela definição de Goffman (1961), reforçada por Geertz (1989), o termo conceitual descreve

algo insuficientemente consistente para ser chamado de grupo e insuficientemente desestruturado para ser chamado de multidão; um conjunto de pessoas absorvidas num fluxo de atividade comum e se relacionando umas com as outras em termos desse fluxo (GOFFMAN apud GEERTZ, 1989, p.193).

Ao contexto da minha análise, o conceito de reunião concentrada corresponderá aos eventos onde ganham forma os inúmeros atos

\footnotetext{
${ }^{2}$ A pesquisa que originou o artigo foi realizada entre janeiro e julho de 2012, privilegiando como foco empírico as interações entre atores e instituições do movimento indígena Anacé e dos projetos do Complexo Industrial e Portuário do Pecém (CIPP) nas vilas indígenas de Bolso, Matões e nas sedes municipais de São Gonçalo do Amarante, Caucaia e Fortaleza. Os dados da pesquisa subsidiaram a realização da dissertação apresentada ao Programa de Pós-Graduação em Antropologia Social da Universidade de Brasília (PPGAS/UnB), trabalho composto sob a orientação do professor Dr. Gustavo Lins Ribeiro.
}

Espaço Ameríndio, Porto Alegre, v. 7, n. 1, p. 214-252, jan./jun. 2013. 
POTYGUARA ALENCAR DOS SANTOS - Exumando corpos de índios...

inaugurais, assembleias, reuniões de comissões e outras mobilizações coletivas que aproximam "pessoas do Estado", "representantes anacé" e "funcionários das empresas" dentro de atos interativos que objetivam integrar, decidir e reconhecer competências institucionais e políticas na implementação de projetos governamentais e empresariais de grande escala. Ocasiões onde ficam mais evidentes as composições entre redes e níveis de integração que constituem as dinâmicas do desenvolvimento (RIBEIRO, 1987, 1991 e 2008).

Enquanto a "análise situacional" (GLUCKMAN, 1987; VELSEN, 1987), por exemplo, atém-se ao sistema hierarquizante que localiza os atores num plano estabilizado de interações e posições, o conceito de reunião concentrada garante, por sua vez, dar relevância ao fato de que status hierárquicos e sistemas de prestígio podem ser rompidos e recompostos a todo instante durante uma interação. O conceito de reunião concentrada presta-se, portanto, a uma análise das flexibilidades instantâneas entre as posições dos atores reunidos, privilegiando ressaltar os atos inusitados que podem se desdobrar nos contextos onde se reúnem representantes de vários segmentos partícipes de um evento político.

Como será apresentado nos tópicos seguintes, o conceito de Goffman (1961) reatualizado pela hermenêutica geertziana é o que melhor nos aproxima de uma compreensão dos encontros entre populações anacé e os operadores estatais-privados dos projetos de grande escala. A exposição e análise dos registros etnográficos deixarão em relevo as interfaces entre o processo da emergência indígena - com todas as estratégias de fortalecimento de um etnônimo e atualização da agenda política do grupo - e o próprio crescimento dos projetos desenvolvimentistas, que interferem e são interferidos pelas demandas étnicas no nível das suas "multiescalas de decisões e competências" (SASSEN, 2006, p. 8): dos desafios mais locais que ocorrem na realização do empreendimento às demandas transculturais que envolvem, por exemplo, a manutenção de consórcios empresariais entre países.

No que tange especificamente as populações impactadas por inciativas político-empresariais de grande escala, reforça-se que essa consciência da cultura (SAHLINS, 2004) que ocorre na reatualização de 
POTYGUARA ALENCAR DOS SANTOS - Exumando corpos de índios...

uma denominação étnica e das suas reivindicações é fator centralmente impactante na inciativa do Estado e dos consórcios empresariais em transformar paisagens sociais e ambientais, desde que a presença interferente dessa consciência local estabelece novas formas de processar e empreender um projeto de grande escala no plano da sua inteligência logística e infraestrutural. É nesse sentido que a emergência indígena pode ser relacionada aos mais variados "níveis de integração" envolvidos com a realização de um projeto desenvolvimentista (RIBEIRO, 2008). O conceito de níveis de integração é importante por colocar em realce "os modos de representar pertencimento a unidades socioculturais e político-econômicas que são centrais para a definição de alianças em múltiplos contextos de cooperação e conflito" (RIBEIRO, 2000 , p. 4). Essa definição reforça a proposta de "correlacionar agentes individuais e coletivos com diferentes unidades espaço-sócio-culturais que possuem variadas expressões institucionais e territoriais" (RIBEIRO, 2000 , p. 4). É preciso observar que o conceito de "integração" utilizado pelo autor de maneira alguma reflete relações homogêneas e não conflitivas entre segmentos do mundo estatal-privado e da organização indígena, mas, sim, campos de disputa e de afirmação de poder hegemônico:

Quando nos referimos à integração, estamos tratando de processos complexos de lutas por hegemonia que não podem ser simplificados. Os resultados reais destes processos são sempre derivados do encontro de forças políticas diferentes e frequentemente opostas (RIBEIRO, 2000, p. 4).

Para a minha análise do caso da identidade anacé, a noção de níveis de integração reflete as relações entre segmentos políticos envolvidos central ou indiretamente com a consecução de iniciativas onde projetos de consórcios estatais-privados concorrem com dinâmicas de afirmação político-identitária de segmentos locais. Segmentos esses que acabam participando de um cenário velado ou explícito de disputas/negociações onde cada um procura afirmar-se hegemonicamente dentro de um processo político. 
POTYGUARA ALENCAR DOS SANTOS - Exumando corpos de índios...

\section{A emergência anacé e os projetos do CIPP: uma síntese descritiva de contexto}

O Complexo Industrial e Portuário do Pecém (CIPP) está localizado entre os municípios de São Gonçalo do Amarante e Caucaia, na Região Metropolitana de Fortaleza, Ceará. A costa oeste do estado, ou Costa do Sol Poente, ficou historicamente conhecida por acolher uma série de investimentos do setor de turismo costeiro, notabilizando-se como um dos cinco principais roteiros turísticos do país (RODRIGUES e SANTOS, 2012; PORTO, 2008). Recentemente, após a inauguração do terminal portuário, o cenário produtivo regional vem sofrendo transformações que fazem conviver duas fronteiras desenvolvimentistas: a turística, que depende da "conservação" das zonas de preamar, aproveitadas principalmente pela expansão imobiliária, e a utilização dessa mesma macrorregião para fins da industrialização. É dentro desse cenário local que o CIPP e a emergência anacé passam a se inserir numa trajetória particular de conflitos e negociações que chegam até os dias atuais.

No ano de 2007, o Governo do Estado do Ceará lança o Decreto de Instalação do Complexo Industrial e Portuário do Pecém (CIPP), documento que daria incentivo fiscal e locacional à construção de uma série de empreendimentos privados que iriam ocupar cerca de 19.000 hectares entre os limites dos municípios de São Gonçalves do Amarante e Caucaia ${ }^{3}$. Os municípios se localizam na costa oeste do Ceará, a menos de 50 quilômetros de Fortaleza. Alguns desses projetos são a criação da Companhia Siderúrgica do Pecém S/A., a partir de consórcios entre a Vale S/A., Dongkuk e Posco, que são empresas coreanas, a termelétrica MPX e a refinaria de petróleo Premium II, da Petrobras. Junto como esses empreendimentos, prevê-se a instalação de uma série de empresas-satélites menores.

O CIPP é uma área desapropriada pelo Governo do Estado do Ceará que servirá à criação de um parque industrial anexo ao Terminal Portuário do Pecém, inaugurado em 2002. Dos equipamentos portuários modernos, o Porto do Pecém é citado como um dos terminais mais bem

\footnotetext{
${ }^{3}$ CEARÁ, Governo do Estado. Decreto N. ${ }^{\circ} 28.883$, de 18 de setembro de 2007. Declaração de utilidade pública para fins de desapropriação da área que indica e dá outras providências. Diário Oficial do Estado. Série 2, Ano X, N. ${ }^{\circ} 178,18$ de setembro de 2007.
} 
POTYGUARA ALENCAR DOS SANTOS - Exumando corpos de índios...

localizados geograficamente da costa brasileira, desde que possui a menor distância náutica entre o continente Europeu, os Estados Unidos e o Canal do Panamá4. O equipamento do Porto do Pecém notabiliza-se, portanto, por ser um empreendimento de "alto valor estratégico na economia do Estado brasileiro" (CEARÁ, 2012, p. 33); termos que genericamente justificam $\mathrm{o}$ assolamento promovido por empreendimentos de grande escala sobre paisagens sociais e ambientais onde habitam grupos tradicionais.

Em 1998, durante as obras do Terminal Portuário, quando começaram a ser divulgadas as primeiras desapropriações na região, os moradores da vila indígena de Bolso - localizada no interior do território poligonal destinado à instalação do CIPP - e de outras vilas adjacentes a essa, reunira-se com clérigos e missionários da Pastoral do Migrante, da Igreja Católica, em busca de alternativas de defesa do território ante o avanço dos projetos industriais e portuários da Costa do Pecém. Dos encontros entre os representantes da Pastoral e os habitantes da comunidade surgiram algumas iniciativas: o resgate historiográfico sobre as primeiras ocupações humanas daquela região costeira; registro de narrativas orais de alguns habitantes das vilas; criação de cartilhas e panfletos divulgando as atividades da Pastoral do Migrante e a formação de comissões territoriais destinadas a dialogar com o governo. $O$ resultado desses encontros entre os residentes da vila de Bolso e a Pastoral, alguns anos depois, se apresentava no surgimento de um movimento indígena que respondia pelo etnônimo anacé.

A pesquisa da qual resultou este artigo procurou problematizar e compreender os dois eventos aqui descritos: a constituição e evolução histórica de um projeto industrial-portuário na costa oeste do estado do Ceará visto como um projeto de grande escala (RIBEIRO, 1987 e 1991) com suas articulações ecológicas, humanas e tecnológicas e, numa outra ponta, a emergência indígena anacé, que, até 2010, reivindicava seu território no centro do polígono espacial definido pelo decreto de criação do Complexo Industrial e Portuário do Pecém (CIPP). O problema foi assim definido: como se deram os processos históricos de surgimento dos projetos industriais e portuários e da reatualização da denominação indígena? Qual a história de cada um deles, isoladamente,

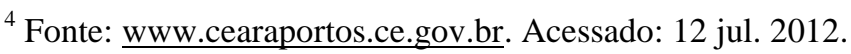


POTYGUARA ALENCAR DOS SANTOS - Exumando corpos de índios...

e no que diz respeito às relações entre os seus segmentos políticos?

Talvez não careça lembrar aqui que a situação dos Anacé não é semelhante à de alguns grupos amazônicos ou de outras regiões do país cuja existência étnica é reconhecida pelo Estado brasileiro e suas instituições. A etnia anacé é resultado de um complexo movimento de emergência étnica recente, sendo formada a partir de uma ação política de resgate e fortalecimento cultural que tem sua história própria e ainda precariamente reconhecida e estudada. Qual a importância disso quando pensamos as fronteiras entre os projetos de grande escala e as populações indígenas nacionais? Essa é uma questão que tem uma implicação fundamental sobre este artigo, cujo enfoque principal se dá sobre os processos advindos do adensamento global das redes de relações, de transformações capitalistas em cenários econômicos e de processos recentes de afirmação identitária.

Minha hipótese é que, na trajetória dos dois processos mencionados - o surgimento dos projetos da Costa do Pecém e a emergência anacé -, ambos promoveram significativas influências políticas em mutualidade. A partir dessa hipótese, a pergunta é recolocada: como, a seus modos, o projeto do CIPP e os Anacé se posicionaram diante das questões que lhes aproximaram territorialmente, mas que os afastavam politicamente nos últimos anos? E que "composições" e capacidades históricas (SASSEN, 2006) propiciaram tanto a emergência étnica quanto o surgimento das iniciativas desenvolvimentistas do capital industrial-portuário ali instalado? ${ }^{5}$.

O CIPP surgiu como uma área de expansão desenvolvimentista que partia do Terminal Portuário do Pecém - inaugurado em 2002, mas com as primeiras edificações erguidas em 1995 - em direção ao interior do estado do Ceará6. Vários planos diretores foram apresentados até a definição da área poligonal atual do projeto, que conta com quatro

\footnotetext{
5 Por "composições" Sassen (2006) compreende as aproximações entre diversas capacidades técnicas e administrativas históricas, marcadas pelas transformações dos Estados Nacionais, seus processos de desnacionalização e conseguinte surgimento de um sistema-mundo. Para a autora, é a forma compósita das escalas espaço-temporais, com extremidades locais e globais, com eventos de proporções macro e micro, que dão sentido às composições atuais do sistema. Já o conceito de "capacidades" se define pelo conjunto de aprimoramentos em lógicas organizacionais dos Estados que propiciaram mudanças históricas, marcando as transformações e combinações entre territórios, formas de autoridades e direitos, por parte do mecanismo estatal e do mundo empresarial associado a ele.

${ }^{6}$ Fonte: http://www.cearaportos.ce.gov.br/. Acessado em: 12 jun. 2012.
} 
POTYGUARA ALENCAR DOS SANTOS - Exumando corpos de índios...

setores prioritários, um cinturão verde formado por um mosaico de Áreas de Proteção Permanente (APAs) litorâneas e uma área de expansão urbana. Os primeiros quatro setores serão ocupados por projetos de produção de energia termelétrica, refinaria de petróleo e siderurgia, com uma dezena de outras indústrias de base já instaladas nos setores três e dois do atual plano diretor do CIPP7.

Dentro do cenário das iniciativas que envolvem a consolidação do CIPP, a articulação política anacé significou, num primeiro momento, o atraso dos empreendimentos - dado o embargo do Ministério Público Federal (MPF) sobre as obras, além da própria recusa de algumas empresas estatais a dar continuidade à instalação dos seus equipamentos - e, num segundo, a proposição de uma série de negociações que buscaram estreitar as relações entre o Estado e as populações locais (indígenas e não indígenas).

Dentre algumas dessas medidas, consta a criação do Comitê Territorial dos Matões - comissão que reúne agentes do governo, técnicos do setor privado e representantes indígenas e não indígenas para discutir os impactos sociais, econômicos e ambientais dos empreendimentos do CIPP sobre a região. Nesse mesmo sentido, as lideranças indígenas começaram a manter reuniões periódicas com o Governo do Estado do Ceará - muitas vezes com a presença do próprio governador - e com representantes da Petrobras - empresa que prevê a instalação de uma refinaria de petróleo denominada Premium II nas proximidades da vila indígena de Matões. Nesses encontros, as lideranças anacé apontavam as suas áreas de interesse dentro da poligonal delimitada pelo Complexo Industrial e Portuário do Pecém (CIPP), e o próprio governo explicou a escolha das áreas delimitadas pelo seu Decreto. Como resultado de meses de negociação, decidiu-se, em acordo com a representação anacé, que as populações indígenas seriam "desapropriadas" e realocadas num território a ser adquirido pelo governo a partir da escolha do grupo. Hoje, o perímetro territorial escolhido pelo movimento anacé está avaliado em R\$ 40 milhões; quantia assegurada pelo Governo do Estado perante a Petrobras, a FUNAI e o próprio grupo indígena. Essas e outras movimentações

\footnotetext{
${ }^{7}$ Visualização cartográfica do plano diretor do Complexo Industrial e Portuário do Pecém (CIPP). Fonte: http://www2.cearaportos.ce.gov.br/complexo.asp. Acessado: 18 mar. 2012.
} 
POTYGUARA ALENCAR DOS SANTOS - Exumando corpos de índios...

marcaram, nos últimos anos, as relações entre Estado, grupos privados - conscientes da importância nacional da zona portuária do Pecém - e a história recente de reatualização da denominação indígena anacé.

A pesquisa etnográfica na Costa do Pecém é reveladora de uma série de mobilizações históricas que aproximaram técnicos do governo, grupos multinacionais interessados na utilização da estrutura do Porto e populações indígenas. Esses dinamismos locais, dentro das suas histórias próprias, são reveladores de uma série de tensões e acordos entre Estado, capital empresarial e populações locais. Logo no seu início, o objetivo da pesquisa colocava em destaque a necessidade de compreender o surgimento e a transformação desses dois processos a partir das várias composições históricas, ecológicas e políticas que estavam na base do Complexo Industrial e Portuário do Pecém e da emergência anacé decorrente das pressões territoriais exercidas pelos projetos. O avanço dos estudos me levou a compreender que as relações entre as questões desenvolvimentistas e étnicas daquela região precisavam ser analisadas não somente como processos políticos concorrentes, ou em franca situação de disputa territorial, mas, sim, como fenômenos complementares, compósitos, onde os atores acabaram contribuindo para o realinhamento político das suas instituições com base no cenário de conflitos e acordos em que estavam inseridos. E nessa direção surgiu a hipótese que veio a consolidar o interesse da pesquisa.

A seguir, apresento duas situações onde se encontram em interação representantes anacé e agentes de outros segmentos políticos envolvidos com a instalação dos projetos de grande escala daquela região. O primeiro dos relatos aborda uma reunião realizada pelo Comitê Territorial dos Matões, onde participaram indígenas, empresários e agentes do governo; e o segundo é descrição de um dia de visita ao Núcleo de Apoio Local da FUNAI, em Fortaleza.

\section{Duas reuniões concentradas}

\section{i. O Comitê Territorial dos Matões}


POTYGUARA ALENCAR DOS SANTOS - Exumando corpos de índios...

Durante uma conversa com um dos moradores da vila indígena de Bolso fiquei sabendo da existência do Comitê Territorial dos Matões. Meu interlocutor, que pertencia a uma família não indígena, tratou do Comitê como uma "reunião onde se falava sobre os problemas do CIPP". De início, imaginei que pudesse ser uma reunião de associados a uma instituição de base local, como uma associação de moradores. 0 morador que falou da existência desses encontros não especificou quem fazia parte do comitê e o que discutiam no seu interior. As únicas informações foram que eles se reuniam mensalmente nas dependências de uma escola da vila indígena de Matões e que a próxima reunião aconteceria no dia 24 de fevereiro de 2012.

Aproveitei a ocasião do encontro para conhecer a vila indígena de Matões, que dista cerca de oito quilômetros da vila de Bolso. Matões pertence à municipalidade de Caucaia, cidade que divide, junto com São Gonçalo do Amarante, a área poligonal do CIPP. No interior do seu perímetro urbano se localiza o setor que abrigará as obras da refinaria Premium II, da Petrobras. No plano diretor do CIPP, a vila seria parcialmente desapropriada para a ocupação da Refinaria, enquanto uma outra porção funcionaria como "zona de expansão urbana", um perímetro urbano destinado à alocação de mão de obra.

Matões em quase tudo lembrava a vila indígena de Bolso: fileiras de casas de um lado e do outro de uma extensa estrada asfaltada que seguia em direção à Costa do Pecém, onde se encontra o Porto. $O$ silêncio das grandes áreas verdes que circulam as casas de varanda concorre com $\mathrm{o}$ barulho dos caminhões-cegonha, caçambas $\mathrm{e}$ caminhões de containers que cruzam diariamente a localidade. A Prefeitura de Caucaia registra ali cerca de 5.000 habitantes que se dividem entre trabalhadores assalariados das indústrias e do Porto do Pecém, uma pequena parcela de funcionários públicos que trabalha no posto de saúde e nas duas escolas do distrito, comerciantes, pequenos agricultores e criadores de animais. Em menor número, existem os pescadores marítimos que, anos atrás, antes da instalação do Porto, iam até a costa pescar e negociar peixes e crustáceos.

Assim como em Bolso, há cerca de 20 anos, Matões era constituída por umas poucas dezenas de casas espalhadas ao longo de um pequeno trecho do tabuleiro litorâneo. As residências estavam 
POTYGUARA ALENCAR DOS SANTOS - Exumando corpos de índios...

dispostas ao longo de uma vereda por onde passavam apenas animais e pessoas em direção às roças de milho, feijão e mandioca plantadas nas baixadas e nas beiras de córregos intermitentes. O Porto e a necessidade de ampliar as rodovias de acesso vieram a alargar os caminhos por onde antes passavam comboios de animais levando lenha e alimentos colhidos nos roçados.

Embora impactadas pelo mesmo empreendimento, notei que as vilas possuem organizações políticas diferentes, com atores e preocupações diversas. A vila de Bolso possui a Associação dos Moradores do CIPP presidida e composta por não indígenas que se posicionam contrariamente aos interesses étnicos anacé, enquanto a vila de Matões possui o Comitê Territorial que recebe apoio do movimento indígena. As diferenças entre essas duas organizações residem no fato de que a primeira é mais centrada nos assuntos de interesse fundiário e a segunda em discutir problemas gerais relacionados à implantação do CIPP. Assim, para a primeira, discutir preços de indenizações de particulares é muito mais importante do que discutir as políticas governamentais de combate à transmissão de doenças sexualmente transmissíveis e difusão de drogas na região de expansão da hinterlândia portuária, preocupação que ocorre à segunda com a sua visão abrangente sobre os problemas ocasionados pelo projeto industrial.

Os interesses políticos de ambas as vilas são divididos, embora ambas sejam afetadas pelas mesmas dinâmicas. O que as unifica é o movimento indígena, que possui famílias cadastradas em Bolso, Matões, Santa Rosa e Japoara; as duas últimas estão fora da área decretada aos projetos industriais e portuários. Embora unificadora, a organização indígena é rechaçada pela população não indígena local, que tem menor número populacional, como um “'bando' de gente que se reúne escondido nos quintais das casas" e que não permitem a participação de indivíduos não indígenas nos seus encontros. Criou-se uma ideia geral entre as famílias não indígenas de que o movimento anacé é uma reunião de particulares que discutem, elaboram e executam planos que favorecem exclusivamente as famílias indígenas, não se importando com os problemas mais urgentes que atingem sem distinção toda a população das vilas rurais do CIPP. Não é ponderado por essas 
POTYGUARA ALENCAR DOS SANTOS - Exumando corpos de índios...

afirmações o fato de que, de início, os Anacé tentaram incorporar famílias as mais diversas no interior do movimento e que todas as ameaças e tentativas de descaracterização da presença indígena executadas pelo Estado e pelos habitantes não indígenas acabaram resultando no recrudescimento da ação política em geral.

Essas clivagens entre identificação étnica e territorial diferenciadas revelam que o movimento indígena anacé não conseguiu unificar as vilas do CIPP ao redor das causas emergenciais para todas as populações ali residentes. Evidencia-se que, para os Anacé, a luta em torno da identificação étnica tornou-se mais importante do que a soma dos problemas localizados nas vilas do CIPP, que são variados e transcendem os litígios territoriais. Produziu-se um processo de dissociação entre o que significavam as "pequenas" demandas locais como direito a indenizações justas, combate à violência nas áreas de crescimento urbano, preservação das áreas de proteção ambiental, investimento em saúde e educação nas localidades, etc. - e o que significava a grande disputa por reconhecimento político e jurídico da pertença étnica.

Descobri que a reunião do Comitê Territorial de Matões ocorreria na sede do Sindicato dos Trabalhadores do Comércio de Minérios e Derivados de Petróleo de Fortaleza (SINTRAMICO). A sede sindical era o local onde mensalmente aconteciam os encontros. À minha chegada, estavam presentes o articulador local dos encontros do Comitê, dois representantes de associações comunitárias de vilas localizadas próximas ao perímetro costeiro e um representante da Secretaria de Educação (SEDUC). Aguardavam uma advogada funcionária de uma das secretarias do Governo do Estado e um engenheiro representante do Consórcio Gavião-Pecém, responsável pela construção das adutoras da transposição do rio São Francisco, de cujas águas chegam até o Terminal Portuário do Pecém depois de viajar mais de 1.000 quilômetros pelo sertão nordestino. O Consórcio Gavião-Pecém surge da aproximação de duas empresas do setor de construção civil responsáveis pela instalação de adutoras do açude Gavião, no CIPP8. A adutora faz parte do movimento de integração dos canais de

\footnotetext{
${ }^{8}$ Consórcio Gavião-Pecém V: Construtora Passarelli Ltda. e Construções e Hydrostec Tecnologia e Equipamentos Ltda.
}

Espaço Ameríndio, Porto Alegre, v. 7, n. 1, p. 214-252, jan./jun. 2013. 
POTYGUARA ALENCAR DOS SANTOS - Exumando corpos de índios...

transposição do rio São Francisco, cuja água deverá abastecer alguns reservatórios dos conjuntos hidrográficos cearenses. O projeto, na sua totalidade, é chamado de Eixão das Águas.

Em uma das reuniões do Comitê Territorial de Matões ouvi uma fala contestatória de Alberto $^{9}$, uma liderança anacé da vila de Matões, à construção do Eixão das Águas, da transposição do rio São Francisco. A sua argumentação se dava num contexto onde estava presente uma série de representantes governamentais. A época daquela reunião era de quase completa incomunicabilidade entre indígenas e Governo, que ainda viviam em extrema animosidade.

Alberto questionava o direcionamento estratégico do Eixão das Águas, no qual um dos trechos terminais ficava o parque industrial do CIPP. Sua questão era: por que as adutoras advindas do grande projeto de transposição do rio São Francisco não passavam pelos municípios atingidos pelos longos períodos de estiagem do Estado, a exemplo dos que se localizam no Sertão Central? A quem elas serviam, de fato? Logo em seguida, a liderança respondia a própria pergunta nominando os grupos econômicos que seriam beneficiados com o projeto de transposição: polo agroexportador da Bacia do Rio Jaguaribe, no sertão leste do Ceará, polo industrial de Fortaleza e Complexo Industrial e Portuário do Pecém.

A liderança indígena apontou o problema das cidades sertanejas que eram atravessadas pelas adutoras, lembrando que as águas dos canais eram negadas àquelas populações do semiárido. Segundo ele, vigilantes diurnos e noturnos armados faziam rondas ao redor dos canais de concreto para que nenhum morador da localidade viesse a extrair a água que passava pelo escoadouro de superfície. Por outro lado, esses mesmos canais desembocavam em extensas regiões agrícolas pertencentes a uma meia dúzia de latifundiários da região central do Ceará. No antes tórrido sertão cearense, agora, eram plantadas culturas de melancia, melão, abacaxi, mamão, banana e flores ornamentais. Produtos cuja grande maioria atravessaria o Atlântico, através do Porto do Pecém, em direção aos mercados holandês, estadunidense e ibérico, principalmente.

\footnotetext{
${ }^{9}$ Ao longo de todo o artigo, optou-se por ocultar os nomes próprios das pessoas citadas, salvo no caso de pessoas públicas.
}

Espaço Ameríndio, Porto Alegre, v. 7, n. 1, p. 214-252, jan./jun. 2013. 
POTYGUARA ALENCAR DOS SANTOS - Exumando corpos de índios...

Por fim, Alberto argumenta que as adutoras do Eixão das Águas fazem parte dos chamados "benefícios às portas" cedidos do Governo às empresas internamente ao CIPP. Ainda criticando o favorecimento do setor privado por parte de um projeto que dizia procurar "resolver o problema do camponês do semiárido", o líder anacé apontava os prejuízos causados pelas obras de implantação da adutora subterrânea no seu trecho final, na vila de Matões: soterramento de mananciais de água doce, destruição do manguezal e assoreamento de riachos e rios.

Com discurso semelhante àquele proferido pela liderança indígena, o pronunciamento de um morador não indígena da vila de Matões abria a sessão daquela tarde. No local do encontro, estavam presentes representantes da Secretaria de Meio Ambiente do Estado do Ceará (SEMACE), da Secretaria de Educação (SEDUC), uma advogada ligada a um órgão do Governo Federal e dois representantes da Prefeitura Municipal de Caucaia, além de uma dezena de moradores da região. Na sua fala, o morador de Matões tratou do soterramento da única nascente de água que havia em toda a extensão da vila, prejuízo causado pelas obras da adutora que já havia sido comentado pela liderança indígena em outra reunião. O morador procurou explicar como as obras foram avançando sobre a nascente, como os quintais foram sendo aos poucos tomados pelas montanhas de areia e pedras retiradas das escavações. Sua queixa, assim como a de muitos que acrescentavam informações à sua fala, recaiu sobre o descumprimento por parte do Consórcio Gavião-Pecém de um compromisso firmado, no contexto daquelas reuniões, de promover reparos nas vias urbanas da vila indígena por onde a tubulação subterrânea havia sido disposta.

A explanação dos problemas por parte dos moradores, que agora procuram participar coletivamente da discussão, é interrompida pela representante da Secretaria do Meio Ambiente do Governo, que pede para "todos ouvirem as explicações do representante do Consórcio". O engenheiro representante do Consórcio começa apresentando as intervenções técnicas da obra que causaram os transtornos. Explicou a razão do soterramento da nascente de água e prometeu que o Consórcio iria procurar restaurá-la antes que as obras fossem concluídas. Um dos moradores lembra que aquele compromisso já havia sido firmado há mais de seis meses, e que a "comunidade" não 
POTYGUARA ALENCAR DOS SANTOS - Exumando corpos de índios...

acreditava mais que o problema fosse resolvido. Alguém eleva a voz afirmando que as obras do Consórcio configuram um "crime ambiental".

Depois da fala do engenheiro, a advogada se interpõe lançando uma explicação de ordem jurídica, relacionada à utilização dos recursos da região. Ela lembra que todos os recursos localizados no interior da poligonal do CIPP são "bens decretados pelo Estado", o que lhe garante o usufruto a fins de instalação do CIPP: fábricas, adutoras, ferrovias, rodovias, etc. Nenhuma interposição de lei ambiental poderia contradizer o direito do Estado em se utilizar dos recursos na região, por isso o caso do soterramento do "manancial de água não configurava nenhum crime, estava tudo em conformidade com o direito que assiste o Decreto de ocupação do CIPP". Nesse momento, um jovem anacé se levanta ao final da fala da advogada e lembra que "em nenhum lugar do mundo se destrói um prédio com pessoas circulando dentro dele" e que não entende porque logo ali, onde as pessoas ainda utilizavam da água do manancial, o governo agia como se não existissem pessoas. Sua fala, oposta aos argumentos da advogada, foi tornada irrelevante diante dos outros pontos de pauta.

Em certo momento, quando o assunto do manancial da vila indígena de Matões destruído pelas obras da adutora foi invisibilizado por outras questões, uma liderança anacé presente solicitou ao Governo que as matas litorâneas do setor leste do CIPP, onde fica a APA do Cauípe, fossem incorporadas ao "cinturão verde do Complexo", explicando que além de serem fontes de recursos e estarem à margem das iniciativas industriais centrais do CIPP, a região era um "território sagrado anacé" onde eram executados cerimoniais de pajelança e onde as crianças da Escola Indígena de Matões eram levadas para desenvolverem atividades de campo. A gestora da APA do Cauípe presente afirmou que há grandes chances da incorporação daquelas matas ao interior da área verde do projeto e que um plano de manejo ambiental poderia pensar a incorporação territorial das matas à APA. $O$ caso foi registrado pela representante da Secretaria do Meio Ambiente que propôs que o assunto constasse entre os pautados pelo próximo encontro do Comitê.

Depois de algumas reuniões do Comitê, percebi que o movimento indígena anacé não mobiliza uma grande quantidade de representantes 
POTYGUARA ALENCAR DOS SANTOS - Exumando corpos de índios...

para participar dos encontros. Sempre avistei somente um representante anacé. Em outras oportunidades, como na inauguração de um programa do Governo dentro do CIPP, estavam presentes apenas três lideranças. Números inexpressivos diante das 403 famílias indígenas cadastradas 10. Entretanto, as localidades rurais, as vilas de pescadoras, as associações comunitárias sempre enviam vários associados, muitas vezes vindos de lugares distantes da região. É comum que os moradores custeassem suas próprias passagens para chegar ao local das reuniões. Sobre a participação das lideranças indígenas nesses eventos, percebi que há um grupo específico formado por três ou quatro homens que se revezam, fazendo o papel de mediadores no repasse das informações e de porta-vozes da opinião do movimento indígena.

Conversando com um representante de uma Prefeitura de cuja municipalidade é atingida pelo projeto, em uma reunião do Comitê, descobri que aquela organização foi criada na gestão do governador Tasso Jereissati, na década de 1990, quando se iniciavam as obras portuárias do CIPP. A proposta de criação de um comitê territorial foi do sociólogo e professor efetivo do Departamento de Sociologia da Universidade Federal do Ceará (UFC) André Haguette, que procurava articular pessoas, a nível local, que pudessem discutir e levar informes e demandas ao Governo sobre os problemas relacionadas à instalação do Complexo. Num primeiro momento, o Comitê atuava "autonomamente". A maioria dos seus membros eram moradores da vila de Matões e poucos eram os funcionários do Estado e das empresas interessados em se fazerem presentes nos encontros mensais.

Inúmeros problemas ambientais e sociais associados à evolução das obras do setor I e II do projeto, principalmente, causaram o surgimento de representações judiciais contra as obras do CIPP. Nesse momento, o Ministério Público Federal (MPF) passa a promover embargos às obras: rodovias em áreas a serem desmatadas, escavações a fim de instalação de gasodutos, entre outros. O governo passa, então, a sofrer pressão dos grupos empresariais, que querem as áreas disponíveis para a execução das primeiras edificações dos seus equipamentos. É em meio às cobranças do setor privado de melhorias das infraestruturas do CIPP e respostas aos problemas judiciais

\footnotetext{
${ }^{10}$ Fonte: Núcleo de Apoio Local da FUNAI no Ceará.
} 
POTYGUARA ALENCAR DOS SANTOS - Exumando corpos de índios...

levantados pelo Ministério Público Federal (MPF) que o Governo do Estado do Ceará, através de uma comissão que foi denominada de "G Mais" (Grupo de Monitoramento de Ações Institucionais e Setoriais do CIPP), passa a se aproximar de maneira coordenada de todos os assuntos pautados, debatidos e encaminhados pelo Comitê Territorial de Matões. O ambiente das reuniões do Comitê se provou adequado à aproximação dos atores envolvidos direta ou indiretamente com as obras do Complexo. É a partir da criação do $G$ Mais que representantes do Governo e dos vários grupos empresariais passam a frequentar com assiduidade e a interferir nas reuniões do Comitê. Passados alguns anos, quase todas as pautas, os assuntos de debate e os encaminhamentos dos encontros são decididos pelo Governo e pelas representações do setor privado, diminuindo, dessa maneira, a interferência das demandas anacé, mas não as eliminando de todo.

A leitura de algumas das atas de reuniões do Comitê Territorial mostra uma intromissão gradual dos assuntos da pauta governamental no âmbito das questões mais específicas trazidas pelas populações da vila indígena de Matões. De uma situação de protagonismo inicial como gestores locais do Comitê, onde a comunidade propunha e buscava encaminhamentos, passa-se a um regime de quase absoluta submissão aos interesses públicos locais pelos interesses dos consórcios estataisprivados. Embora o Comitê seja, em grande medida, articulado por um morador da vila de Matões - um professor não indígena de sociologia que leciona na escola de ensino fundamental e médio da localidade -, os assuntos de importância prioritária, a composição das pautas e a articulação das pessoas que estarão presentes nos encontros são propostas que partem do grupo de funcionários das secretarias do governo do estado.

Dentro da Comissão Territorial dos Matões, o grupo de funcionários do governo propôs uma ação estratégica e conjunta entre secretarias estaduais da educação, da saúde, da infraestrutura, meio ambiente, membros do Instituto de Desenvolvimento Agrário do Ceará (IDACE) e do Instituto Brasileiro de Meio Ambiente e Recursos Renováveis (IBAMA). Todos voltados a mediar problemas envolvendo as queixas comunitárias. A partir do "bom êxito" da Comissão, o Governo propôs a criação do Centro de Convivências do CIPP, que seria um 
POTYGUARA ALENCAR DOS SANTOS - Exumando corpos de índios...

centro predial onde continuariam ocorrendo as reuniões do Comitê e onde se montaria uma base administrativa dos problemas advindos da consolidação dos Complexos, tais como: problemas ambientais, como os danos causados às Áreas de Proteção Permanente (APA) que circundam o CIPP, problemas relacionados à saúde pública da população, como a endemia de doenças sexualmente transmissíveis (DSTs) que já ocorre na região, cadastramento e capacitação de mão de obra local, além de outras questões.

Em certo momento da reunião do Comitê, uma representante do grupo do governo pediu que fosse cedido um pequeno instante de fala ao representante da empresa Verde Vivo de reflorestamento, que atua na construção e manutenção do cinturão verde do projeto. 0 representante empresarial traz o problema do roubo de mudas e destruição das cercas da APA do Cauípe, que circunda a região norte da área do CIPP. Ele é enfático ao acusar os moradores da vila de Matões de prejudicarem as ações da Verde Vivo nas etapas de reflorestamento da mata nativa da APA e das suas proximidades, onde já teriam sido plantadas cerca de 100.000 mudas de várias espécies nativas. Solicitava que as pessoas não retirassem as mudas ou danificassem as cercas, pedindo também que denunciassem as ações de quem estivesse fazendo.

Nesse momento, a advogada que representado a Secretaria de Infraestrutura lembra a todos(as) que ações de depredação como essas poderiam facilmente ocasionar punições penais a quem estiver executando-as ou facilitando para que elas acontecessem. Esperava-se que "tipos de vandalismo" como esses fossem evitados para que intervenções judiciais também fossem poupadas. A mesma advogada acusava que outros casos de depredação a obras já haviam sido registrados, como a retirada da sinalização rodoviária que servia aos caminhoneiros que trafegavam em direção ao Porto e o roubo de equipamentos das empreiteiras que atuavam no interior da vila de Matões. O restante do encontro do Comitê Territorial de Matões dedicou-se, naquele dia, à apresentação de um programa do Governo do Estado do Ceará: o Pacto pelo Pecém. O programa é um plano de ação que objetiva reunir informações, agregar atores produtivos e populações locais em torno das execuções das metas futuras do 
POTYGUARA ALENCAR DOS SANTOS - Exumando corpos de índios...

Complexo Industrial e Portuário do Pecém. Àquela época, estávamos a cinco meses da inauguração do programa.

Antes de finalizar o encontro daquela tarde, um representante do Setor de Altos Estudos e Assuntos Estratégicos, da Assembleia Legislativa do Estado do Ceará, pediu a palavra para anunciar a proposta do Pacto pelo Pecém. Em meio a todo o ambiente de denuncia promovido pelas populações indígenas, principalmente, e avaliação dos problemas mais urgentes a serem sanados nas relações entre o CIPP e essas populações, a fala do representante da Assembleia Legislativa parecia desconexa, ao tempo que também desviava a atenção dos assuntos que sempre incomodaram ao Governo, justamente aqueles relacionados aos efeitos negativos dos projetos. Junto ao funcionário da Assembleia Legislativa se posicionou uma representante do grupo de comunicação da Companhia Siderúrgica do Pecém (CSP), que havia chegado atrasado à reunião. Além de reforçar a importância do programa que estava em articulação, dado que "poderia ser uma resolução prática para os 'pequenos transtornos' causados pelas obras", a funcionária da CSP aproveitou para divulgar a sua participação dentro do Comitê, como representante dos grupos empresariais da Companhia Siderúrgica e afirmou que estava à disposição dos moradores de Matões e vilas adjacentes. Enquanto isso, outros membros da mesma empresa de comunicação distribuíam camisas, bolsas, canetas e chaveiros que portavam a logomarca da Companhia, entre os presentes.

A incorporação dos assuntos de Governo e do setor privado no Comitê buscou encontrar repostas não judiciais aos problemas ocasionados pelos projetos. Os pronunciamentos dos gestores públicos, no interior da Comissão, são sempre positivos quanto ao interesse em resolver os problemas comunitários e encontrar soluções rápidas às questões emergenciais e satisfatórias tanto às populações quanto ao setor privado; essas mesmas estratégias já são conhecidas através de outros registros etnográficos de audiências públicas realizadas nos períodos de implementação de grandes projetos (BARAÚNA e MARIN, 2011). Resolvendo os problemas judiciais, ao tentar mediar os conflitos no interior dos encontros do Comitê, o Estado conseguiu também imprimir velocidade a todas as obras do CIPP, sejam aquelas empreendidas pelo Governo - como as rodovias, ferrovias e adutores -, 
POTYGUARA ALENCAR DOS SANTOS - Exumando corpos de índios...

sejam aquelas previstas pelas indústrias que passariam a ocupar o Complexo. O que é notável, entre todas essas movimentações, é a presença cada vez mais evidente do governo em todos os assuntos relativos à área poligonal do CIPP, que em boa parte ainda é um grande canteiro de obras do setor público à espera da ocupação empresarial.

No espaço de mediação entre os três segmentos em que se transformou o Comitê, o Estado sempre procurou apresentar as qualidades, a grandiosidade e o impacto econômico das obras em instalação ou a serem instaladas na região. Nesse sentido, de um contexto que deveria ser de denúncias e propostas de resolução de demandas sociais, passou-se a um momento de autopromoção governamental e de exaltação em tom salvacionista das obras do CIPP: a obra que viria a resolver os problemas econômicos históricos do Estado e da região Nordeste, que viria a modernizar e ampliar o setor industrial cearense.

\section{ii. Exumando corpos de índios: uma visita à FUNAI (NAL - Ceará)}

No relato que será apresento a seguir, trato do contexto onde me encontrei com o superintendente da FUNAI (Ceará) e um cacique anacé, na sede do órgão público, em Fortaleza, quando então fui interpelado a esclarecer os interesses da minha pesquisa diante da instituição. $\mathrm{Na}$ ocasião, pude colher, entre outras informações, narrativas da etnicidade que recontavam histórias de perseguição e morte de lideranças indígenas do passado, tratando também dos locais onde esses líderes foram enterrados e transformados, desde então, em territórios sagrados para o movimento anacé. Compreende-se que a retomada desse regime de memória da identificação étnica (FABIAN, 2001), muitos anos depois das perseguições e massacres de indígenas ocorridos ainda no contexto colonial, surge como uma reavaliação dos elementos simbólicos e práticos que estão envolvidos na luta reivindicatória que tem seus referenciais na territorialidade e na identidade categórica que representa o movimento.

Entre as pessoas que conheci nas vilas indígenas de São Gonçalo do Amarante, Ana era uma jovem anacé que esteve presente no período 
POTYGUARA ALENCAR DOS SANTOS - Exumando corpos de índios...

das missões da Pastoral do Migrante na região. Passei algumas tardes em convívio com Ana, que trabalhava na pequena mercearia mantida pela sua família na vila indígena de Bolso. Nas nossas conversas, evitava abordar assuntos relativos ao início do movimento indígena, fatos atuais que envolviam o grupo, suas ações políticas ou desafios na luta pelo reconhecimento. Sabia que essas informações não poderiam ser cedidas antes que a minha presença fosse discutida pelo conselho indígena anacé. Ao invés, procurei saber da sua opinião sobre todas as transformações sofridas na vila e no seu entorno decorrentes dos projetos do CIPP. Afora os interesses mais estritos da pesquisa, que sempre nos levavam a uma conversa cheia de ressalvas, procurei compartilhar do seu cotidiano mais imediato, registrar as formas de convívio dos habitantes a partir da mercearia, onde conheci outros jovens e ampliei o meu grupo de amigos. Tudo era muito recente até então. Havia me tornado morador da vila de Bolso há menos de três meses.

Numa certa tarde, notei que Ana se comportava de forma estranha. Após minha chegada, ela ficou por um longo período sem trocar palavras ou respondendo às minhas indagações com frases curtas e em tom desinteressado. Foi então que lhe perguntei se estava tudo bem. De imediato, ela me perguntou: "Você está se apresentando às famílias indígenas como um funcionário do Estado?". Fiquei bastante surpreso com a sua indagação. Respondi-lhe que não e perguntei-lhe de onde esta informação havia surgido. Ana me explicou que algumas famílias indígenas que visitei haviam levado a informação para o conselho indígena anacé de que existia um "homem andando por aí" que se aproximava das famílias se apresentando como um funcionário do governo interessado em fazer uma pesquisa dentro da comunidade. As lideranças anacé que já me conheciam, e que tinham recebido o meu pedido de realização da pesquisa junto às famílias indígenas, associaram esse "estranho" à minha presença.

Ana me falou que a interpretação do movimento indígena foi a de que eu estava me apresentando como funcionário do governo para convencer as famílias a dar informações. Em vista disso, o conselho anacé resolveu encaminhar a minha carta de recomendação da Universidade de Brasília (UnB), com todos os meus dados, ao posto da 
POTYGUARA ALENCAR DOS SANTOS - Exumando corpos de índios...

FUNAI, em Fortaleza. A FUNAI, por sua vez, segundo o que Ana me informou, já havia pedido esclarecimentos à sede de Brasília sobre a minha presença, solicitando informações relativas aos meus interesses de pesquisa. A primeira reação do superintendente da FUNAI, ao saber da minha presença, foi de se perguntar por que um antropólogo estava fazendo levantamento de dados na área e ainda não tinha se apresentado ao posto da FUNAI. E que o comando repassado às lideranças indígenas foi de que evitassem qualquer diálogo com o antropólogo, pedindo que me informassem que a FUNAI solicitava que eu fosse à sua sede administrativa em Fortaleza.

Diante dessas informações, minha primeira reação foi negar que em algum momento teria me apresentado como "funcionário do Governo", e que sempre fui franco ao apresentar os meus interesses de pesquisa e de onde vinha. Estava ali em realização de uma pesquisa que por sua vez estava vinculada a um programa de pós-graduação da Universidade de Brasília. Expliquei-lhe que não havia nenhuma vantagem em me apresentar como pessoa do Estado, em vista da relação conflitiva que as famílias tinham com tudo que dizia respeito às ações governamentais na região. Expliquei-lhe que nunca havia me reportado à FUNAI por entender que as primeiras pessoas que deveriam saber da minha presença eram os próprios Anacé, e não um órgão mediador. Entendia que o movimento indígena era formado por sujeitos autônomos, capazes de responder por suas orientações políticas e de se posicionar, melhor do que ninguém, sobre as suas decisões. Para mim, sempre foi menos importante procurar saber como a FUNAI retrata os Anacé do que como os Anacé retratam a FUNAI. Por tudo isso não havia me dirigido de início à Fundação.

Mas naquele momento seria impossível buscar uma compreensão de Ana apenas apresentando minha palavra com boas intenções e sem provas sobre o que afirmava, afora uma declaração da minha universidade de origem que já havia sido encaminhada ao conselho anacé. Entendi que a melhor coisa a fazer seria me reportar à FUNAI do Ceará e procurar resolver o mal-entendido. Pensando sobre as razões de terem associado meu nome ao funcionalismo do Estado, compreendi que a ideia de vir de Brasília e ser antropólogo era o bastante para produzir associações de significados que não me 
POTYGUARA ALENCAR DOS SANTOS - Exumando corpos de índios...

encaixavam em outro tipo que não no "funcionário público", como muitos outros que, antes de mim, haviam visitado aquelas famílias. No dia seguinte, agendei um encontro com o superintendente da FUNAI no Ceará. Sua secretária confirmou que nos encontraríamos na tarde do dia seguinte.

Não tinha esperanças de obter informações sobre o grupo Anacé a partir da FUNAI. O ambiente geral não propiciava que a instituição fosse transparente aos meus interesses de pesquisa. Além do mais, as lideranças anacé já tinham produzido toda uma caracterização suspeita sobre a minha presença em campo, relatando uma certa "postura ambígua" dentro da vila. Imaginava que a passagem pela FUNAI objetivava desfazer os mal-entendidos ocorridos no meu contato com as famílias indígenas, apresentar as intenções do meu projeto de pesquisa e discutir a viabilidade de adquirir alguns dados junto à instituição. Ao final daquela tarde, percebi que as conclusões obtidas após o encontro foram mais valiosas do que qualquer outro dado que a instituição pudesse me oferecer.

A sede da FUNAI, no Ceará, atua nas áreas de fiscalização, assistência, compra e renda indígena, educação diferenciada, agricultura e atividades indígenas, contando com 12 funcionários que se desdobram no atendimento de 13 etnias que somam mais de 22.400 indígenas $^{1}$. As aldeias estão localizadas em distâncias que variam de 20 a $400 \mathrm{~km}$, a partir de Fortaleza. Sua sede se localiza num prédio de dois andares amplo e bem localizado, se pensado a sua distância em relação às principais vias de acesso que levam ao centro da cidade de Fortaleza e ao bairro que abriga os principais órgãos do poder administrativo do Estado. Fui recebido pelo superintendente, que estava sentado à frente de uma longa mesa onde estavam em cima a minha carta de recomendação expedida pela Universidade de Brasília (UnB), repassada à FUNAI pelas lideranças anacé, e outro documento que depois soube ser uma espécie de aviso da FUNAl do Ceará à sede de Brasília que informava do meu levantamento de dados junto à área indígena.

Ao me sentar à mesa, a primeira indagação foi: "Então o senhor é o antropólogo de Brasília?". E depois que afirmei que sim, o superintendente me surpreende com outra pergunta: "O que o senhor

${ }^{11}$ Fonte: http://funaiceara.blogspot.com.br/ Acessado: 22 dez. 2012. 
POTYGUARA ALENCAR DOS SANTOS - Exumando corpos de índios...

faz entre os Anacé?". O que seguiu foi uma longa tentativa de apresentar minhas origens institucionais e a finalidade do meu levantamento de dados dentro da área do CIPP. Tratei de alguns pormenores relativos aos objetivos da pesquisa, procurando responder a outros questionamentos feitos pelo superintendente: "Como foi que chegou nos Anacé? Por que resolveu fazer pesquisa na área? Por que não veio até a FUNAl antes de iniciar o levantamento de dados?".

As perguntas não apelavam apenas por respostas objetivas, elas eram feitas sob uma atitude de suspeita às minhas intenções enquanto pesquisador antropólogo. Algum tempo depois, descobri que há cerca de um ano uma antropóloga da Fundação Darcy Ribeiro (FUNDAR), de Brasília, junto com um assistente indígena, haviam feito estudos antropológicos na região a pedido da usina termelétrica da empresa MPX. No diagnóstico antropológico, os pesquisadores produziram descrições que retratam as famílias anacé que se negavam a sair da área do CIPP como

[...] famílias de classe média, empregados na administração pública ou nas empresas, além de detentoras de extensões de terras suficientes para não dependerem de terras de terceiros onde trabalhar para garantir a pequena produção familiar e o complemento da renda com a comercialização de parte dessa produção [...] Ali (na vila de Bolso) foram localizadas situações de famílias em condições de vida mais precárias que a das famílias cadastradas como indígenas entrevistadas (FUNDAR, 2009, p. 34).

O documento foi recebido de maneira negativa pelo movimento indígena anacé, principalmente pelas famílias de Bolso e Matões, que foram citadas inúmeras vezes. As lideranças leem o diagnóstico antropológico produzido pela Fundação Darcy Ribeiro como mais um esforço em prol da descaracterização da presença indígena e uma tentativa de deslegitimar os seus direitos.

A minha origem - uma instituição localizada em Brasília - junto com uma confusão de termos feita pelas lideranças anacé da carta de recomendação da Universidade de Brasília (UnB) me associaram ao nome da Fundação; fatos que foram decisivos à criação de uma suspeita por parte dos Anacé sobre a minha presença em campo. A confusão foi 
POTYGUARA ALENCAR DOS SANTOS - Exumando corpos de índios...

causada pelo fato de constar, no rodapé da carta de apresentação, como parte do endereço do programa de pós-graduação a expressão "Campus Darcy Ribeiro"; inscrição que se assemelhava a "Fundação Darcy Ribeiro". Logo, as lideranças anacé passaram a pensar que a pesquisa que desenvolvia estava a serviço da Fundação, e não da Universidade.

À medida que ia explicando a confusão de termos, o superintendente fazia expressões de não acreditar no que dizia. E ao final de uma longa tentativa de me retratar diante de tudo que tinha acontecido, ele dá o seu parecer: eu deveria interromper o levantamento de dados. Fui instruído que casos idênticos no Ceará sofreram com a intervenção da Polícia Federal e que alguns indígenas, eles mesmos, estavam a combinar minha expulsão da vila de Bolso. Para o superintendente da FUNAI, em todo esse cenário havia "muita gente grande" e um levantamento de dados independente não poderia, eventualmente, contradizer o levantamento de dados da FUNAI.

Ao final da sua fala, quando já ia questionar algumas das suas posições, o superintendente me faz uma surpresa: "E por coincidência, olha quem é que está por aqui: O cacique Pedro". O cacique Pedro, que é reconhecido como o articulador de todas as famílias anacé em torno da luta reivindicatória pela terra, surgiu de uma porta que se encontrava às minhas costas e sentou à minha frente. Obviamente, acredito que a sua presença logo naquele dia na sede da FUNAI não tinha nenhuma coincidência com a data do meu encontro com o superintendente. Tinha certeza que ele havia sido convidado pelo superintendente para se fazer presente à nossa conversa. Sem expressar palavra alguma, o Cacique permaneceu em silêncio a escutar as "prevenções e conselhos" do superintendente. Tentei os convencer de que muitos dos objetivos da pesquisa ainda estavam a ser cumpridos. Em certo momento, o representante anacé intervém na nossa conversa e, assim como o superintendente, lembra que "as pressões que o movimento indígena sofre são muitas nesses casos [...] alguns boatos que as pessoas dizem por aí sobre nós só fazem atrapalhar, por isso se evita passar informações a qualquer um". Nesse momento, o superintendente nos pede licença para se retirar da sala, precisa atender a um telefonema. Diferente do superintendente, o cacique Pedro se interpõe à conversa de 
POTYGUARA ALENCAR DOS SANTOS - Exumando corpos de índios...

forma mais aberta e amena, dando atenção aos meus argumentos e até relatando alguns conflitos que se instauraram em decorrência da existência de pesquisadores de "má-fé que se fizeram de amigo da comunidade para pegar informações"; em clara referência aos pesquisadores contratados pela empresa MPX. "Os Anacé já sofreram muito na mão desse povo!", repetia a liderança.

E a conversa ente nós, durante a longa pausa cedida pelo superintendente, seguiu trazendo algumas informações novas relativas ao movimento indígena. Notei um interesse do Cacique em me apresentar um relato convincente à presença anacé na cidade de São Gonçalo do Amarante. Em algumas de suas narrativas reproduzidas ali mesmo, lembrou que, ainda na sua infância, seu avô the contava a história do "massacre da Lagoa do Banana", onde muitos índios anacé foram sacrificados. Ao final do que contava - lembrava Pedro -, seu avô Ihe dizia: "pois meu filho, a gente faz parte desse povo aí, dos índios [...] mas não conte pra ninguém!". Ora ou outra dizia: "mas são muitas histórias que eu tenho guardado [...] quando vi que foi a hora de falar sobre elas, eu fui lá e contei a verdade".

Em certo momento, pergunto sobre o caso da liderança anacé que foi enterrada no Cemitério do Cambeba. A história conta que uma liderança anacé, no início da convivência entre brancos e índios na vila de Bolso, havia morrido e sido enterrada no chamado Cemitério do Cambeba, que fica nas proximidades da vila. Durante os anos de intervenção do Ministério Público Federal (MPF) sobre a questão indígena anacé, o Cemitério foi citado como um local sagrado para o movimento indígena por guardar vestígios materiais da ancestralidade indígena em forma de monumentos e cenários históricos que eram tematizados pelas narrativas anacé. $O$ relato reproduzido no Parecer Técnico do MPF traz que:

[...] o índio que chamavam de Cambeba morreu no tronco de uma Pitombeira. Aí começaram a enterrar outros por lá e passou a ser chamado Cemitério do Cambeba. Houve uma intensa mobilização dos Anacé, no período de 1999 a 2001, quando o cemitério, que está dentro da área declarada de utilidade pública para fins de desapropriação, esteve sob ameaça de ser removido para a instalação do Complexo. Essa possibilitada foi descartada por um tempo, porém em 
POTYGUARA ALENCAR DOS SANTOS - Exumando corpos de índios...

reuniões realizadas neste ano de 2008, engenheiros e técnicos do IDACE informaram aos Anacé que o cemitério teria que ser removido (BRISSAC et al, 2009, p. 24).

Desde 2010, aproximadamente, os Anacé têm sentado com o governo objetivando apontar as terras reivindicadas pelo movimento indígena e conhecer as áreas do interior do CIPP que são prioritárias às obras; como é o caso do setor II do CIPP, para onde está prevista a instalação da refinaria Premium II, da Petrobras. Um dos acordos celebrados foi que mil hectares do setor II, além de outras porções territoriais reivindicadas pelos Anacé na parte central do CIPP, seriam "trocados" por uma área a ser adquirida no entorno da área do projeto, em região a ser escolhida pelo próprio movimento indígena. Dentre as áreas cedidas pelo movimento indígena se encontra aquela do Cemitério do Cambeba, sobre a qual perguntei ao cacique Pedro. Até 2009, os Anacé reivindicavam a área alegando a existência de ancestrais da etnia enterrados ali, sendo compreendido como lugar sagrado pelo grupo indígena.

Ao perguntar ao cacique Pedro sobre a história do índio que havia sido enterrado no Cemitério do Cambeba, obtive a seguinte resposta: "Todo mundo sabe, que o índio não foi enterrado ali, mas na serra da Japoara!". A Serra da Japoara, que é outra área reivindicada pelo movimento indígena, fica localizada no entorno da área do CIPP e em nada conflita com os interesses territoriais do governo. O que fica perceptível na afirmação de que o índio Cambeba teria sido enterrado em outro lugar que não no cemitério ancestral é o fato de que, dois anos após todas as reivindicações pela área original do cemitério, esta afirmação decorre do processo de reelaboração dos "regimes de memória" do grupo étnico (FABIAN, 2001), quando então abriu mão de porções territoriais para o governo, que em troca se comprometeu a criar uma reserva indígena numa região exterior à área poligonal do projeto do CIPP, além de prever de investir R\$ 4 milhões em políticas sociais destinadas às famílias anacé.

A reelaboração dos regimes de memória anacé - quando o símbolo do índio morto é "exumado" de um lugar a outro do território (do Cemitério do Cambeba para a Serra da Japoara) - não pode ser 
POTYGUARA ALENCAR DOS SANTOS - Exumando corpos de índios...

refletido aqui fora de todas as composições políticas envolvendo interesses de segmentos dos consócios público-privados, mobilizações do discurso étnico objetivado o reconhecimento do seu território e os acordos firmados que vieram a reposicionar tanto as estratégias da organização indígena, quanto os investimentos do governo. É a própria inflexão no espaço interacional das relações entre Estado e lideranças anacé que veio a operar na reelaboração das estratégias indígenas de atuação em planos "multiescalares"; para recordar a terminologia conceitual de Sassen (2006) e também informar o seu valor quando na análise da participação dos grupos étnicos - aparentemente superdependentes de uma referência às escalas "do local" (do territorial) - no destino das iniciativas do mundo estatal-privado.

Argumenta-se, aqui, a partir do caso do símbolo exumado do índio enterrado no Cemitério Cambeba, apresentado na narrativa do cacique Pedro, que a atuação da organização indígena no interior de todas as capacidades técnico-administrativas de gerenciar pessoas e bens de capitais (territórios, máquinas, recursos naturais, etc.) foi decisiva na reavaliação dos projetos do governo - as obras da Petrobras no CIPP foram atrasadas em cinco anos - e nas políticas ambientais e sociais de viabilização de obras: praticamente todas as empresas do CIPP tiveram que reorientar os seus Planos Básicos de Ação (PAC) em vista da presença indígena e da necessidade de produzir diagnósticos antropológicos que avaliassem a situação das famílias anacé na macrorregião do projeto.

Esse encaixe, ou "composição" (SASSEN, 2006), entre estratégias da organização indígena e velocidades operacionais dos segmentos consorciados é um elemento que se lê como um compósito de forças onde cada unidade em relação procurou estabelecer benefícios às suas iniciativas: a organização indígena estabelecer-se enquanto instituição centralizadora dos apelos por direito ao reconhecimento público concentrando-se sobre o direito às terras tradicionais -; e o Estado e as empresas, consolidar prazos e os projetos em vista da manutenção das parcerias do qual a totalidade do projeto do Complexo Industrial e Portuário depende para se realizar.

Em leitura ampliada das mudanças de posicionamentos e estratégias políticas, pode-se afirmar que o movimento indígena anacé 
POTYGUARA ALENCAR DOS SANTOS - Exumando corpos de índios...

e as quase 40 organizações públicas, privadas ou mistas constituem a composição de todas as "redes de desenvolvimento" (RIBEIRO, 2008) necessárias à consecução do projeto do CIPP. Chamo atenção ao fato de que entre "os múltiplos segmentos" envolvidos com as obras (RIBEIRO, 2008, p. 111), as suas várias velocidades de operação, capacidades técnicas e configurações de parcerias é preciso encaixar o componente da presença étnica não simplesmente como "o segmento impactado", ou descompensado pelo jogo político, mas como organização centralmente interferente nos destinos mais infraestruturais e logísticos do projeto de grande escala.

Ainda na sede da FUNAI, cacique Pedro me falou que possuía documentos que retratavam o passado dos índios anacé, e que esses documentos eram um segredo de família que o seu pai havia repassado para ele. Nesses documentos - que se negou a dizer se eram epístolas, textos históricos ou outro tipo de registro - constava relatada boa parte dos conflitos que ocorreram no passado envolvendo índios e fazendeiros, além do nome de várias lideranças anacé. E ainda durante o nosso diálogo, comenta: "Você sabe, não é? A gente índio é meio misturado!". A referência à mistura surgiu no momento em que fazia a descrição dos seus avôs: "Eles eram alvos e dos olhos claros". Geração aquela que, segundo Pedro, já se falava da existência dos Anacé que à época ainda não haviam se autoafirmado. O retorno do superintendente à sala de reuniões da FUNAl, onde eu conversava com a liderança anacé, veio a interromper o nosso diálogo.

Reatualizações da pertença étnica e redes de desenvolvimento: uma síntese de análise

Este artigo trata das relações entre um caso de emergência indígena e um processo de implementação de uma iniciativa desenvolvimentista estatal-privada. Por fazerem parte de fenômenos decorrentes de construções históricas regionais tanto de um discurso de etnicidade como de programas políticos e econômicos estratégicos e multiescalares que acabaram se cruzando, os segmentos envolvidos nessas iniciativas precisavam ser analisados por dois vieses analíticos: 
POTYGUARA ALENCAR DOS SANTOS - Exumando corpos de índios...

um que privilegiasse a leitura da reelaboração étnica como um caso particular de afirmação de uma identidade categórica (BARRETTO FILHO, 1994; PACHECO DE OLIVEIRA, 1998) e o outro que enfocasse as composições e níveis de integração entre organizações administrativas, agendas e capacidades políticas consorciadas em diversas escalas por grupos estatais e privados (RIBEIRO, 2008; SASSEN, 2006). Durante essa tentativa, sobressaiu-se o problema do caso etnográfico escolhido: como a emergência anacé e as iniciativas desenvolvimentistas da Costa do Pecém construíram seus projetos políticos e foram influenciados por movimentações mútuas ao longo das suas histórias? A proposição desta questão esclarecia que, ao invés de concentrar minha análise sobre os impactos ambientais e sociais dos projetos governamentais e privados sobre as populações locais, deveria considerar também as estratégias indígenas de enfrentamento e participação política nos destinos dos projetos a serem implementados nas terras ocupadas pelos Anacé.

Tentei mostrar que a história do ressurgimento dos Anacé enquanto grupo organizado, demandante de direitos diferenciados e de uma identidade categórica exclusiva, desdobrou-se em meio às inciativas e aos problemas das organizações envolvidas com os projetos do Complexo Industrial Portuário do Pecém (CIPP). De movimento indígena sem reconhecimento regional e com algumas esperanças de auxílio jurídico por parte do Ministério Público Federal (MPF), a organização indígena anacé se transformou em segmento envolvido tanto com os destinos do projeto quanto com a definição dos seus impactos. De qualquer forma, é impossível deixar de observar que essa participação não escondeu as assimetrias de poder, os danos e as iniquidades de toda ordem que ocorrem quando o Estado promove transformações bruscas em paisagens sociais e ambientais onde residem essas populações.

A evidência dessa agência histórica dos Anacé permite, a meu ver, repensar o paradigma do impacto que sobressai nas análises sobre conflitos entre populações tradicionais e projetos nacionais de grande infraestrutura (VAINER, 2008; ZHOURI e OLIVEIRA, 2007). É comum que o enfoque principal de boa parte desses estudos sejam os efeitos sempre danosos que os interesses territoriais, tecnológicos e ambientais do Estado causam sobre as populações locais. Aqui decidi incorporar 
POTYGUARA ALENCAR DOS SANTOS - Exumando corpos de índios...

fortemente as iniciativas políticas dos atores, que procuram se inserir e propor reavaliações nas formas de administração, compreensão e atuação na composição política que interfere nos destinos de obras infraestruturais, políticas públicas regionais e programas desenvolvimentistas nacionais.

Outro resultado deste empreendimento foi demonstrar que a mobilização indígena vai para além da criação de núcleos de liderança ou formas de associação com instituições políticas estatais-privadas. A própria modificação da agência política desses atores é sentida intimamente nos regimes do imaginário narrativo do grupo, na reprodução da história recente e antiga de emergência política e na revitalização e projeção de um novo senso de administração de um território. Como já discutiu Maia (2011), na sua tese etno-histórica, a participação interferente de lideranças anacé indígenas dentro dos "projetos do Estado" vem de longa data, remontando a atuações de indivíduos da etnia na consolidação do modelo administrativo dos aldeamentos e vilas indígenas na colônia portuguesa nas Américas. A participação indígena no período colonial foi estratégica para a implementação e o gerenciamento da máquina administrativa portuguesa. Embora muitas vezes reduzidos à condição de capatazes da Coroa, algumas lideranças indígenas do Nordeste brasileiro não tardaram a compreender que "era necessário fazer escolhas e tomar decisões que fossem menos deletérias para as suas próprias vidas no território de vivência comum (...) buscando a partir de suas inserções alguma vantagem para os seus" (MAIA, 2011 , p. 43); motivo essencial da participação de lideranças anacé nos meandros do antigo regime e na atualidade das intervenções do Estado republicano sobre os seus territórios.

Assim como no período colonial, no qual se tem registrado a própria presença de indivíduos anacé em meio a essas articulações políticas, as lideranças continuam exercendo um triplo papel de influência nos destinos dos assuntos do Estado: [i.] na reivindicação da presença indígena como um fator que deve ser levado em conta se é que se deseja a consolidação de interesses desenvolvimentistas; [ii.] no reconhecimento da presença étnica local por parte do Estado como uma tentativa de controlar as disputas e conflitos procurando compensar 
POTYGUARA ALENCAR DOS SANTOS - Exumando corpos de índios...

dívidas socioambientais com o grupo étnico; e [iii.] na utilização da situação conflitiva da implementação das obras como um momento de reavaliação da conduta política do grupo, divulgação das suas demandas mais imediatas e ampliação das redes de relações com instituições estatais e privadas, garantindo a sua participação nos processos onde são fabricadas certas decisões.

Os dados etnográficos aqui apresentados contribuem para relembrar que reelaborações étnicas se dão em meios complexos e multiplamente compartilhados por sujeitos políticos e institucionais. Assim, o despertar de uma categoria político-identitária (ARRUTI, 1997) não é obra apenas de um coletivo organizado e fechado em torno de uma causa pertinente somente ao grupo, mas é também resultante da recepção que a sociedade envolvente faz da mobilização étnica e de todas as negociações, das redes de parcerias e de disputas em torno do exercício de autoridades e direitos no contexto em que o movimento se insere. É nesse sentido que a emergência anacé e a organização mais ampla dos seus atores se fortaleceram justamente no espaço das relações e contradições internas às redes de desenvolvimento que constituem o projeto do CIPP. De fato, o movimento indígena da Costa do Pecém surge em decorrência do avanço das obras do Complexo e reavalia suas práticas também em decorrência dos desafios que os consórcios político-empresariais impõem à manutenção e ampliação das suas iniciativas. Entendo, assim, que os movimentos onde identidades e organizações são despertas podem também expressar tensões das transformações que acontecem numa região, num país ou no nível global. Por esse motivo, as emergências indígenas podem ser vistas como fenômenos intimamente impactados pelo que Sassen (2006) tratou por transformações fundacionais em sistemas complexos, noção que abrange todas as dinâmicas econômicas e os desafios políticos que ocorrem ao Estado e à sua capacidade de administrar territórios, autoridades e direitos no momento histórico que a autora chamou de era das composições globais.

Considerações finais: reafirmações étnicas em meio às dinâmicas do sistema-mundo

Espaço Ameríndio, Porto Alegre, v. 7, n. 1, p. 214-252, jan./jun. 2013. 
POTYGUARA ALENCAR DOS SANTOS - Exumando corpos de índios...

Uma das discussões teóricas deste artigo procurou relacionar uma parte da teoria de Saskia Sassen (2006), a partir do conceito de composições, com os comentários sobre níveis de integração apresentados por Ribeiro (2000 e 2008). Inspirado em Sassen (2006) questionei como foram possíveis composições entre capacidades históricas do Estado e das iniciativas privadas nacionais e regionais, buscando compreender os processos sociológicos e históricos que propiciaram essas aproximações na consecução das iniciativas que fundaram o CIPP - um projeto de alto interesse estratégico para a região Nordeste e para o país - e que acabaram resultando na emergência anacé.

As ideias de capacidades e multiescalaridade dos processos enfatizam que o desenvolvimento do Estado Nacional e do sistemamundo não se dá simplesmente pela transposição de lógicas organizacionais, mas pela instauração de novas capacidades históricas em administrar territórios e criar autoridades legais; capacidades essas que foram paulatinamente adquiridas a partir da intrusão dos interesses do capital nos assuntos da administração estatal. Nesse mesmo sentido, os regimes de fundação de novas lógicas econômicas e políticas não se dão pela exclusão de escalas espaço-temporais, mas pela conformação de várias delas, onde o local tem potencial de manifestar em si indícios de processos de maior amplitude. Ao mesmo tempo, esses processos de maior amplitude são também interferidos por iniciativas que partem de instâncias locais.

No caso que interessa a este artigo, a possibilidade de relacionar processos micros - a reelaboração étnica causada pelos avanços de projetos desenvolvimentistas na região - e macros - a própria complexidade dos projetos do CIPP, suas ampliações e modernizações se explica pela forma complexa com que a reafirmação indígena, com os seus desdobramentos políticos, cruzou-se com a história da implementação do Complexo Industrial e Portuário. Os dados etnográficos e históricos indicaram que os avanços de cada um dos setores industriais do CIPP em direção ao interior da região onde residem os Anacé foram acompanhados de inúmeras contestações e justificativas étnicas que aos poucos se transformaram de um conflito 
POTYGUARA ALENCAR DOS SANTOS - Exumando corpos de índios...

instaurado entre o governo e os indígenas em uma negociação estudada que trouxe para o interior do planejamento da viabilidade das obras as demandas étnicas. Isso não quer dizer, porém, que todos os apelos das famílias anacé foram contemplados no decorrer das negociações, nem que as assimetrias de poder e os efeitos danosos ao bem-estar dessas populações foram subsumidos por completo. As relações entre esses segmentos continuam sendo conflitivas e reveladoras da desproporção entre impactos que as tomadas de decisão do governo e da organização indígena causam nos destinos do projeto.

Nesse contexto, as lideranças anacé procuraram se inserir em várias frentes de atuação e em diferentes níveis de integração que iam da própria organização interna e local do movimento, que tem como sede as vilas de Matões e Bolso, às diversas instâncias que marcam a presença do governo e das empresas na região. Situações que evidenciam que a própria atuação indígena procurou se mobilizar através de multiescalas político-empresariais (SASSEN, 2006), de diferentes níveis de integração, buscando entender e acompanhar a complexidade organizacional e territorial do projeto. De um modo geral, o caso da emergência indígena anacé e da implantação do Complexo Industrial e Portuário do Pecém (CIPP) proporcionou indicar as composições que se dão entre territórios e autoridades diante das quais grupos minoritários se veem obrigados a se inserir em negociações do direito ao reconhecimento étnico e de benefícios territoriais e sociais com segmentos do mundo estatal-privado. Analisar essas composições significa sublinhar a participação da reivindicação étnica enquanto movimento contra-hegemônico também decorrente das transformações do sistema-mundo.

As contribuições de Gustavo Lins Ribeiro com o conceito de níveis de integração e a perspectiva de considerar um projeto por dentro aperfeiçoaram a minha tentativa de entender o desenvolvimento e a globalização a partir de jogos de poder internos aos contextos reais de disputa territorial e de negociação de identidades. O conceito de níveis de integração já adiantava que "os modos de representar pertencimento a unidades socioculturais e político-econômicas (...) são centrais para a definição de alianças em múltiplos contextos de cooperação e conflito" (RIBEIRO, 2000, p. 2). A capacidade de etnografar esses contextos e 
POTYGUARA ALENCAR DOS SANTOS - Exumando corpos de índios...

suas interconexões internas e as diversas formas de identificação dos atores com os segmentos coloca em desafio a tentativa de estudar um projeto por dentro. O conceito se mostrou importante à minha análise quando procurei "correlacionar agentes individuais e coletivos com diferentes unidades espaço-sócio-culturais que possuem variadas expressões institucionais e territoriais" (RIBEIRO, 2000, p. 4). A referência a uma ideia de integração utilizada pelo autor reflete a existência de processos complexos e de luta por hegemonia que envolvem forças políticas diferentes e frequentemente opostas.

Como foi observado por Barretto Filho, ao dissertar sobre a emergência indígena tapeba - que se avizinha territorialmente e se assemelha politicamente à emergência anacé -, "é na simultaneidade das relações entre níveis da vida e organizações sociais" (BARRETTO FILHO, 1994, p. 24) e também na coexistência entre decisões do Estado, no espaço das competições por territórios e seus recursos, na soma entre acontecimentos em contextos locais, regionais e transculturais que a reelaboração da etnicidade desses povos deverá ser processada e compreendida.

\section{Referências bibliográficas}

ARRUTI, José Maurício Andion. A emergência dos remanescentes. Mana, Rio de Janeiro, v. 2, n. 3, p. 7-38, 1997.

BARAÚNA, Gláucia Maria Quintino; MARIN, Rosa Elizabeth Acevedo. O "fator participativo" nas audiências públicas das hidrelétricas de Jirau, Santo Antônio e Belo Monte. In ZHOURI, Andréa (Org.). As tensões do lugar: hidrelétricas, sujeitos e licenciamento ambiental. Belo Horizonte: Editora UFMG, 2011. p. 93-125.

BARRETTO FILHO, Henyo Trindade. Tabepas, tapebanos e pernas-de-pau de Caucaia, Ceará: da etnogênese como processo social e luta simbólica. Série Antropologia, Brasília, v. 165, p. 1-30, 1994.

BRISSAC, Sérgio et al. O povo Indígena Anacé e seu Território Tradicionalmente Ocupado (Parecer Técnico No 01/09). Ministério Público Federal. Procuradoria da República no Estado do Ceará. Fortaleza, abr. 2009.

CARDOSO DE OLIVEIRA, Roberto. O índio e o mundo dos brancos. Campinas: 
POTYGUARA ALENCAR DOS SANTOS - Exumando corpos de índios...

Editora da UNICAMP, 1964.

CEARÁ, Assembleia Legislativa. Pacto pelo Pecém: iniciando o diálogo. Fortaleza: Imprensa da Assembleia Legislativa, 2012.

FABIAN, Joannes. Ethonology and history. In. Anthropology with attitud: critical essays. Satnford: Stanford University Press, 2001. p.70-85.

FUNDAR - FUNDAÇÃO DARCY RIBEIRO. Diagnóstico antropológico e socioeconômico do impacto global da UTE Energia Pecém, localizada no Complexo Industrial e Portuário do Pecém (com Parecer Ambiental). Produto 3 do Plano de Trabalho que integra o contrato realizado entre a Fundação Darcy Ribeiro e a REX Empreendimentos Imobiliários Ltda, 2009.

FURTADO, Celso. O Brasil pós-milagre. Rio de Janeiro: Paz e Terra, 1981.

GEERTZ, Clifford. A Interpretação das culturas. Rio de Janeiro: Ed. Guanabara, 1989.

GLUCKMAN, Max. Análise de uma situação social na Zululândia moderna. In FELDMAN-BIANCO, Bela (Org.). Antropologia das sociedades contemporâneas: Métodos. São Paulo: Global, 1987. p. 227-344.

GOFFMAN, Erving. Encounters: two studies in the sociology of interaction. Indianápolis: U.I., 1961.

MAIA, Lígio de Oliveira. A implantação do diretório em vila Viçosa Real (CE): incerteza, colaboração e negociação indígenas (c. 1759-1762). In: PACHECO DE OLIVEIRA, João (Org.). A presença indígena no Nordeste. Rio de Janeiro: Contra Capa, 2011. p. 21-47.

PACHECO DE OLIVEIRA, João. Uma "etnologia dos índios misturados"? Situação colonial, territorialização e fluxos culturais. Mana, Rio de Janeiro, v. 1, n. 4, p. 47-77, 1998.

PORTO, Luana Cavalcanti. Políticas de turismo e território: paradoxos entre o Prodetur/Ne e o programa de regionalização do turismo. $1^{\circ}$ Encontro Internacional Sobre Gestão em Turismo (EIGTUR), Ouro Preto, Minas Gerais, Brasil - 25 a 29 de março, 2008, p. 23-38.

RIBEIRO, Gustavo Lins. Poder, redes e ideologia no campo do desenvolvimento. Novos Estudos, São Paulo, v. 80, p. 109-125, 2008.

Empresas transnacionais. um grande projeto por dentro. São Paulo/Rio de Janeiro: Marco Zero/ANPOCS, 1991.

A condição da transnacionalidade. In. RIBEIRO, Gustavo Lins. Cultura e política no mundo contemporâneo. Brasília: Edunb, 2000. p. 93-129. 
POTYGUARA ALENCAR DOS SANTOS - Exumando corpos de índios...

Cuanto mas grande mejor? Proyectos de gran escala, una forma de produccion vinculada a la expansion de sistemas economicos. Desarrollo Economico, Buenos Aires, n. 105, p. 3-27, 1987.

RODRIGUES, Lea Carvalho; SANTOS, Potyguara Alencar. Populações tradicionais, turismo e conflitos territoriais: estudo etnográfico em Tatajuba, Ceará. Cadernos do Leme, Campina Grande, v. 4, 2012, p. 1-27.

SAHLINS, Marshall. Que é iluminismo antropológico? Algumas lições do século XX. In: Cultura na prática. Rio de Janeiro: Editora UFRJ, 2004. p. 535-562.

SASSEN, Saskia. Territory, authority, rights: form Medieval to Global Assemblages. Princeton/Oxford: Princeton University Press, 2006.

VAINER, Carlos. O conceito de "Atingido": uma revisão do debate. In: ROTHMAN, Franklin Daniel (Org.). Vidas alagadas: conflitos socioambientais, licenciamento e barragens. Viçosa: UFV, 2008. p. 39-63.

VELSEN, J. Van. A análise situacional e o método de estudo de caso detalhado. In: FELDMAN-BIANCO, Bela (Org.). Antropologia das sociedades contemporâneas:. Métodos. São Paulo: Global, 1987. p. 345-374.

ZHOURI, Andréa; OLIVEIRA, Raquel. Desenvolvimento, conflitos sociais e violência no Brasil rural: o caso das usinas hidrelétricas. Ambiente e Sociedade, Campinas, v. 10, p. 119-135, 2007. 